\title{
Nursery cultivation regimes, plant functional attributes, and field performance relationships in the Mediterranean oak Quercus ilex L.
}

\author{
P. Villar-Salvador ${ }^{\mathrm{a}, *}$, R. Planelles ${ }^{\mathrm{b}, 1}$, E. Enríquez ${ }^{\mathrm{c}}, \mathrm{J}$. Peñuelas Rubira ${ }^{\mathrm{a}}$ \\ ${ }^{a}$ Centro Nacional de Mejora Forestal "El Serranillo”, DGCONA, Ministerio de Medio Ambiente, Apdo. 249, 19004 Guadalajara, Spain \\ ${ }^{\mathrm{b}}$ Instituto Nacional de Investigaciones Agrarias (INIA), Departamento de Medio Ambiente, Apdo. 8111, 28080 Madrid, Spain \\ ${ }^{\mathrm{c}}$ EUITF de Madrid, Universidad Politécnica de Madrid, Avda. Ramiro de Maeztu s/n, 28040 Madrid, Spain
}

Received 15 November 2002; received in revised form 1 October 2003; accepted 20 February 2004

\begin{abstract}
In this study we have addressed the effect of nitrogen fertilisation and shading used during nursery growth on the functional quality of Quercus ilex L. (holm oak) seedlings and their outplanting performance in an abandoned continental Mediterranean cropland. Three $\mathrm{N}$ fertilisation regimes: high and low fertilisation (154 and $34 \mathrm{mg} \mathrm{N}$ per plant, respectively) and no fertilisation, combined with two shade levels (full sun and $45 \%$ shade) were studied. Fertilisation increased the shoot size, shoot to root mass ratio $(\mathrm{S} / \mathrm{R})$, root $\mathrm{N}$, and both shoot and root $\mathrm{P}$ concentration of the plants produced in the nursery. Fertilisation also enhanced the capacity of new root formation. Neither tissue $\mathrm{K}$ nor root mass was affected by $\mathrm{N}$ fertilisation. Shading increased $\mathrm{S} / \mathrm{R}$ and root $\mathrm{K}$ concentration but reduced both shoot and root $\mathrm{N}$ concentration. Two years after planting, unfertilised seedlings had higher mortality and grew significantly less than those cultivated at both a low and a high fertilisation level. Shading during nursery growth had no influence on the outplanting performance of holm oak seedlings. Plants with a larger shoot and higher S/R had lower mortality and grew faster than those with a smaller shoot and lower S/R. Outplanting performance of holm oak seedlings was related with root $\mathrm{N}$ and $\mathrm{P}$ concentration and with RGC. No relationship was found with either shoot nutrient concentration or root mass. We conclude that high $\mathrm{N}$ fertilisation of holm oak seedlings in the nursery can improve their early field establishment in the afforestation Mediterranean abandoned croplands.
\end{abstract}

(C) 2004 Elsevier B.V. All rights reserved.

Keywords: Afforestation; Holm oak; Nitrogen; Nursery fertilisation; Shading; Root growth capacity

\section{Introduction}

Quercus ilex L. (holm oak) is one of the most important woody species in the forest communities

\footnotetext{
* Corresponding author. Tel.: +34-949-212651; fax: +34-949-211096.

E-mail addresses: pvsalvador@mma.es (P. Villar-Salvador), planelle@inia.es (R. Planelles).

${ }^{1}$ Tel.: +34-913476739.
}

of the western Mediterranean basin. The use of this evergreen sclerophyllous tree in the Spanish reforestation programs has strongly increased in the last 10 years overcoming Pinus species, which were widely used in the past. $Q$. ilex seedlings have lower survival and growth in plantations when compared with other Mediterranean woody species (Baeza et al., 1991; Bocio et al., 2001), indicating that it is very vulnerable to stress factors during their early life stages, especially during the first summer drought. Shading and 
irrigation in the field can enhance its post-planting performance (Rey-Benayas, 1998) but greatly increases reforestation costs.

The poor development of $Q$. ilex plantations could also be attributed to the low quality of the planted seedlings. Low quality plants might exhibit morphological and physiological characteristics that impair their performance under stressful conditions. Nursery cultivation regimes can strongly determine the functional characteristics of seedlings and their field performance. For instance, fertilisation is a nursery tool that strongly determines plant functional attributes. In conifers from mesic environments, fertilisation enhances new root growth capacity (RGC) and the outplanting survival and growth of seedlings (Landis, 1985; Timmer et al., 1991; van den Driessche, 1992). However, high $\mathrm{N}$ fertilisation can reduce drought tolerance (Tan and Hogan, 1995) and root biomass, and it increases leaf area, shoot size and the shoot-root mass ratio (S/R) (Canham et al., 1996; Graff et al., 1999; Berger and Glatzel, 2001). It can be expected that the seedlings that exhibit these attributes may be more vulnerable to water stress than the seedlings with the opposite traits (Leiva and Fernández-Alés, 1998). For instance, water status and survival among woody Mediterranean species has been negatively related with the S/R (Lloret et al., 1999).

Plant production in Spanish forest nurseries starts in the early spring and ends in mid fall. Most Mediterranean evergreen species are grown with little amount of fertilisers. Specifically, seedlings of evergreen oak species are frequently not fertilised as it is considered that the acorn nutrient reserves will fulfil the plant needs in the nursery. The plants raised without fertilisation or with little fertiliser are considered more resistant to Mediterranean environmental conditions than the high-fertilised ones. However, the influence of nursery fertilisation on the outplanting performance of Mediterranean woody species has received almost no attention, and to the best of our knowledge, no study on Mediterranean oak species has been reported hitherto. In the Mediterranean conifer Pinus halepensis, high-fertilised seedlings had lower mortality than the low-fertilised plants when planted in a semiarid region, in spite of their larger size and higher S/R (Oliet et al., 1997). This result suggests that nursery fertilisation might improve the field establishment of seedlings under
Mediterranean conditions, as it has been reported in regions that are more humid.

As holm oak is a late succession species and seedling recruitment benefits from canopy shade of mature tress and early successional species (Lookingbill and Zavala, 2000), it is frequently cultivated under a half shade. This practice is considered to produce higher quality seedlings because it presumably reduces foliar damage caused by the heat load and high irradiation that occurs during the summer. However, shading induces similar morphological and mass allocation responses in the plants as high $\mathrm{N}$ fertilisation (Callaway, 1992; Canham et al., 1996) and reduces seedling water stress tolerance (Aranda et al., 2001), which may impair their field performance. Nevertheless, there is a lack of studies dealing with the influence of nursery shading on the outplanting performance of forest species.

The general objective of this study is to analyse the effect of different cultivation conditions in the nursery on the outplanting performance of $Q$. ilex seedlings. Specifically, we have addressed the following questions: (1) How do growth, tissue nutrient concentration and the production of new roots of $Q$. ilex seedlings respond to $\mathrm{N}$ fertilisation and shading? (2) Can the early field survival and growth of holm oak seedlings be improved by the $\mathrm{N}$ fertilisation and the shading regime used in the nursery? (3) What functional traits of $Q$. ilex seedlings are related to their successful performance in the field?

\section{Materials and methods}

\subsection{Plant growth and experimental design}

On January 1998, acorns of Q. ilex subsp. ballota from an inland Spain provenance (La Mancha-Montiel) were sown in 36 Forest Pot $300^{\mathbb{R}}$ containers. This container has 50 cavities of $300 \mathrm{~cm}^{3}$, it is $18 \mathrm{~cm}$ high and growing density is 387 plants $\mathrm{m}^{-2}$. Cavities have a square shape and inside walls have vertical antispiralling ribs. A 3:1 (v:v) peat-vermiculite mixture was used as substratum and one acorn per cavity was sown. To avoid frost damage, plants were initially grown in a glass greenhouse in which temperature ranged from 4 to $25^{\circ} \mathrm{C}$ and radiation was approximately $50 \%$ of that outside. 
In mid-May 1998, seedlings were moved outside. Half of the plants were placed in a tent $(3 \mathrm{~m} \times 3 \mathrm{~m} \times$ $4 \mathrm{~m}$ ) made with a shade cloth that reduced radiation to $55 \%$, while the remainder were left under full sun. This shading is applied in many Spanish nurseries for growing broadleaf species. Three fertilisation levels were differentiated: no fertilisation (unfertilised Original Kasper peat), low and high $\mathrm{N}$ fertilisation. In the low $\mathrm{N}$ fertilisation treatment, nutrients were supplied as a $\mathrm{N}-\mathrm{P}-\mathrm{K}(15-7-15)$ slow release fertiliser mixed in the peat $\left(1 \mathrm{~kg} \mathrm{~m}^{-3}\right.$ of peat; Original Kasper B6), which contained $34 \mathrm{mg} \mathrm{N}, 16 \mathrm{mg} \mathrm{P}$ and $34 \mathrm{mg} \mathrm{K}$ per seedling. In the high $\mathrm{N}$ fertilisation, each plant was supplied with $154 \mathrm{mg} \mathrm{N}$ and the same amount of $\mathrm{P}$ and $\mathrm{K}$ as the low fertilisation treatment. This was achieved by supplementing a total of $120 \mathrm{mg}$ of $\mathrm{N}$ per plant to half of the plants growing in the fertilised peat. This supplement was applied once a week by overhead sprinkling fertirrigation, from the end of May to midSeptember (7.05 mg N per week) utilising a $\mathrm{NH}_{4} \mathrm{NO}_{3}$ fertiliser ( $\mathrm{N}$ richness $33.5 \%$ ). Fertilisation treatments within each irradiation environment were arranged in three blocks, each block being composed by two containers per fertilisation treatment. Plants were kept well watered by irrigating them every 1-3 days.

\subsection{Morphological, nutritional status and root growth capacity measurements}

On November 1998, when plants were 10 months old, 10 plants per treatment and block (five plants per container) were randomly sampled for morphological and nutrient concentration determinations. Shoots were cut at the cotyledon insertion point and separated into leaves and stems, and root plugs were cleaned from the peat. Shoot height was measured as the length of the stem while shoot diameter was measured as the stem thickness at the cotyledon insertion point. Then, all the plant parts were washed with tap water, rinsed in distilled water and dried in a ventilated oven at $65^{\circ} \mathrm{C}$ for $48 \mathrm{~h}$ to measure their dry mass. To assess $\mathrm{N}, \mathrm{P}$ and $\mathrm{K}$ tissue concentration, the shoots and the roots of the sampled plants $(n=10)$ were pooled separately and finely ground. Nitrogen was released by combustion at high temperature in pure oxygen and measured by thermal conductivity using a LECO CHN-600 analyser. $\mathrm{P}$ and $\mathrm{K}$ concentration were determined by vacuum inductively coupled plasma emis- sion spectroscopy (Optima 2000, Perkin-Elmer) after sample digestion in a microwave with $\mathrm{HNO}_{3}$.

In mid-March 1999, a root growth capacity test was set up. Fifteen plants per treatment were planted in 31 pots (one plant per pot) containing perlite. Pots were randomly arranged in three complete blocks in an unheated greenhouse. Plants were irrigated every other day and did not receive any fertilisation. After 22 days, seedlings were cleaned from the potting medium and the number of new roots longer than $1 \mathrm{~cm}$ protruding out of the plug was counted.

\subsection{Planting and field measurements}

Planting was conducted in Santorcaz (Madrid, centre of Spain, $40^{\circ} 29^{\prime} \mathrm{N}, 3^{\circ} 12^{\prime} \mathrm{W}$ ) on a flat site $850 \mathrm{~m}$ a.s.l. on 13 April 1999. The plot had a deep clay loamy soil and was a 10-year old abandoned wheat cropland. Mean annual rainfall and temperature were $490 \mathrm{~mm}$ and $13.1{ }^{\circ} \mathrm{C}$, respectively. The mean maximum and the mean minimum temperature of the hottest and coldest months were 31.5 and $0.1{ }^{\circ} \mathrm{C}$, respectively, and summer drought was typically of 3 to 4-month duration. Experimental design consisted of three complete random blocks, each treatment being hand planted as a 20 -seedling row within each block. The identity of nursery blocks was maintained in the field, i.e. plants of block 1 of each shade environment in the nursery were planted in block 1 in the field and so on. Mortality and growth were recorded at the end of the first and second growing season. Stem volume increase (SVI) and stem volume relative growth rate (RGR) were used as an estimate of plant growth in the field. SVI was calculated from the height of the stem and its diameter as the product of plant height and 1/3 basal area. Diameter was measured immediately above the cotyledon insertion points. Height and diameter were measured up to the nearest 0.1 and $0.01 \mathrm{~cm}$, respectively. RGR was calculated as

$\mathrm{RGR}=\frac{\ln \mathrm{SV}_{2}-\ln \mathrm{SV}_{1}}{t_{2}-t_{1}}$

where $\mathrm{SV}_{1}$ and $\mathrm{SV}_{2}$ are the stem volume of seedlings measured at planting $\left(t_{1}\right)$ and 2 years after planting $\left(t_{2}\right)$, respectively.

The plot was not irrigated in any year and weeds around each plant were controlled by hoeing and herbicides. 


\subsection{Data analysis}

Analysis of variance (ANOVA) was used to determine effects of fertilisation and irradiation regime on both plant morphological characteristics and field performance. The container was considered the experimental unit for morphological data, whereas the block was the experimental unit for the nutrient data. In the ANOVA performed on nursery variables, the block was considered a random factor and was nested within irradiation regime. The mean square of the block within irradiation regime was used as the error term for testing the effect of shading. The mean square of the interaction of fertilisation by block within irradiation regime provided the error term for testing the effect of fertilisation and the interaction of irradiation regime by fertilisation. In the analysis of RGC data and of field mortality and growth, all factors were considered fixed, experimental design was full factorial and sum of squares of interactions between block and the other factors were pooled with the error sum of square. Tukey's test was used to assess differences among mean values.

Relationships of field mortality and growth with RGC and the morphological and nutritional variables were studied by regressions.

\section{Results}

Fertilisation showed a significant effect on all the morphological variables except on root mass (Table 1). Increase in $\mathrm{N}$ fertilisation enhanced the height, diameter, shoot mass, and the $S / R$ of the seedlings, especially in the high fertilisation regime (Table 2). There was also a trend $(P=0.068)$ of fertilisation to increase total leaf mass. Shade had not any significant effect on morphological variables except on $S / R$, which was lower in the seedlings grown under full sun. $\mathrm{N}$ fertilisation did not influence either shoot $\mathrm{N}$ or root $\mathrm{K}$ concentration. However, root $\mathrm{N}$ concentration of the highly fertilised plants was 27 and $24 \%$ higher than that of the unfertilised and the low-fertilised plants, respectively (Table 2). Shaded plants exhibited lower root and shoot $\mathrm{N}$ concentration but higher shoot $\mathrm{K}$ concentration than full-sun grown seedlings, no differences existing in the root $\mathrm{K}$ concentration. $\mathrm{N}$ fertilisation increased shoot and root $\mathrm{P}$ concentration,
Table 1

$F$ ratios derived from the analysis of ANOVA of the effects of nitrogen fertilisation and shade regime on the morphology, root growth capacity and nutrient concentration of $Q$. ilex seedlings

\begin{tabular}{llll}
\hline Factors & $\begin{array}{l}\text { Shade } \\
\text { regime }\end{array}$ & Fertilisation & $\begin{array}{l}\text { Shade regime } \\
\times \text { fertilisation }\end{array}$ \\
\hline Height & $2.61 \mathrm{n} . \mathrm{s}$. & $11.94^{* *}$ & $0.012 \mathrm{n} . \mathrm{s}$. \\
Diameter & $0.072 \mathrm{n} . \mathrm{s}$. & $4.73^{*}$ & $0.79 \mathrm{n} . \mathrm{s}$. \\
Total leaf weight & $0.234 \mathrm{n} . \mathrm{s}$. & $3.83 \mathrm{n} . \mathrm{s}$. & $0.249 \mathrm{n} . \mathrm{s}$. \\
Shoot dry mass & $0.04 \mathrm{n} . \mathrm{s}$. & $4.26^{*}$ & $0.08 \mathrm{n} . \mathrm{s}$. \\
Root dry mass & $1.65 \mathrm{n} . \mathrm{s}$. & $0.17 \mathrm{n} . \mathrm{s}$. & $0.57 \mathrm{n} . \mathrm{s}$. \\
Shoot/root & $7.65^{*}$ & $6.41^{*}$ & $0.129 \mathrm{n} . \mathrm{s}$. \\
Shoot N & $41.2^{* *}$ & $3.49 \mathrm{n} . \mathrm{s}$. & $0.37 \mathrm{n} . \mathrm{s}$. \\
Root N & $14.25^{*}$ & $17.63^{* *}$ & $1.30 \mathrm{n} . \mathrm{s}$. \\
Shoot P & $3.36 \mathrm{n} . \mathrm{s}$. & $5.33^{*}$ & $4.33^{*}$ \\
Root P & $0.84 \mathrm{n} . \mathrm{s}$. & $20.67^{* * * *}$ & $6.86^{*}$ \\
Shoot K & $8.95^{*}$ & $6.03^{*}$ & $0.52 \mathrm{n} . \mathrm{n}$. \\
Root K & $0.001 \mathrm{n} . \mathrm{s}$. & $0.74 \mathrm{n} . \mathrm{s}$. & $0.74 \mathrm{n} . \mathrm{s}$. \\
RGC & $0.33 \mathrm{n} . \mathrm{s}$. & $8.58^{* * * *}$ & $2.32 \mathrm{n} . \mathrm{s}$. \\
\hline
\end{tabular}

For simplicity, the effects of block and of the interaction of block within light $\times$ fertilisation on morphological attributes are not represented; n.s.: $P>0.05$. $^{* *} P \leq 0.05 ;{ }^{* *} P \leq 0.01 ;{ }^{* * *} P \leq 0.001$.

although a significant interaction with shade was observed for both variables (Table 1). In the former, the unfertilised and the highly fertilised plants grown in full sun concentrated more $\mathrm{P}$ in shoots than the shaded ones, no differences existing among the lowfertilised seedlings. In the latter interaction, root $\mathrm{P}$ concentration was positively influenced by $\mathrm{N}$ fertilisation, although this effect was more intense in full-sun exposed plants than in the shaded ones (data not shown).

RGC was positively influenced by $\mathrm{N}$ fertilisation (Table 1), the high-fertilised plants having a three-fold higher new root production than unfertilised plants (Table 2). Shading had no effect on RGC. Shoot dry mass at the end of the nursery growing period was positively correlated with RGC $(r=0.53$, $P=0.023$ ).

After the second growing season in the field, a significant effect of nursery fertilisation on seedling mortality $\left(F_{2,10}=9.76, P=0.0043\right)$, SVI $\left(F_{2,10}=\right.$ $14.20, P=0.0011)$, and on $\operatorname{RGR}\left(F_{2,10}=13.71\right.$, $P=0.001$ ) was observed (Fig. 1). Mortality of the unfertilised plants was on average $40 \%$, which was 2 and 2.6 times higher than the mortality recorded in the low- and the high-fertilised plants, respectively. Mortality tended to occur during the summer period. 
Table 2

Morphology, nutrient concentration and root growth capacity of $Q$. ilex seedlings (means \pm one standard error) cultivated in the nursery with different $\mathrm{N}$ fertilisation and shade regimes

\begin{tabular}{|c|c|c|c|c|c|}
\hline & \multicolumn{3}{|c|}{ Nitrogen fertilisation regime } & \multicolumn{2}{|l|}{ Shade regime } \\
\hline & $0 \mathrm{mg}$ per plant & $34 \mathrm{mg}$ per plant & $154 \mathrm{mg}$ per plant & Full sun & $45 \%$ shade \\
\hline Height $(\mathrm{cm})$ & $12.5 \pm 0.57 \mathrm{c}$ & $14.1 \pm 0.78 \mathrm{~b}$ & $16.2 \pm 0.55 \mathrm{a}$ & $13.2 \pm 0.49$ & $15.3 \pm 0.65$ \\
\hline Diameter (mm) & $4.6 \pm 0.10 \mathrm{~b}$ & $4.9 \pm 0.14 \mathrm{~b}$ & $5.1 \pm 0.12 \mathrm{a}$ & $4.9 \pm 0.11$ & $4.8 \pm 0.12$ \\
\hline Total leaf weight (g) & $0.99 \pm 0.05 \mathrm{a}$ & $1.08 \pm 0.07 \mathrm{a}$ & $1.26 \pm 0.104 \mathrm{a}$ & $1.08 \pm 0.04$ & $1.13 \pm 0.06$ \\
\hline Shoot dry mass $(\mathrm{g})$ & $1.53 \pm 0.08 \mathrm{~b}$ & $1.72 \pm 0.12 \mathrm{~b}$ & $2.02 \pm 0.06 \mathrm{a}$ & $1.73 \pm 0.08$ & $1.78 \pm 0.10$ \\
\hline Root dry mass (g) & $3.31 \pm 0.20 \mathrm{a}$ & $3.39 \pm 0.13 \mathrm{a}$ & $3.24 \pm 0.09 \mathrm{a}$ & $3.49 \pm 0.14$ & $3.14 \pm 0.06$ \\
\hline Shoot mass/root mass & $0.47 \pm 0.02 \mathrm{~b}$ & $0.50 \pm 0.02 b$ & $0.63 \pm 0.02 \mathrm{a}$ & $0.50 \pm 0.02$ & $0.56 \pm 0.02^{*}$ \\
\hline Shoot $\mathrm{N}\left(\mathrm{mg} \mathrm{g}^{-1}\right)$ & $12.7 \pm 0.51 \mathrm{a}$ & $11.7 \pm 0.33 \mathrm{a}$ & $12.8 \pm 0.43 \mathrm{a}$ & $13.2 \pm 0.32$ & $11.7 \pm 0.22^{*}$ \\
\hline Root $\mathrm{N}\left(\mathrm{mg} \mathrm{g}^{-1}\right)$ & $5.2 \pm 0.20 \mathrm{~b}$ & $5.3 \pm 0.20 \mathrm{~b}$ & $6.6 \pm 0.36 \mathrm{a}$ & $6.1 \pm 0.31$ & $5.3 \pm 0.20^{*}$ \\
\hline Shoot $\mathrm{P}\left(\mathrm{mg} \mathrm{g}^{-1}\right)$ & $0.30 \pm 0.018 \mathrm{~b}$ & $0.31 \pm 0.016 \mathrm{~b}$ & $0.35 \pm 0.018 \mathrm{a}$ & $0.34 \pm 0.015$ & $0.30 \pm 0.011$ \\
\hline Root $\mathrm{P}\left(\mathrm{mg} \mathrm{g}^{-1}\right)$ & $0.19 \pm 0.010 \mathrm{~b}$ & $0.22 \pm 0.010 \mathrm{~b}$ & $0.29 \pm 0.028 \mathrm{a}$ & $0.25 \pm 0.03$ & $0.22 \pm 0.01$ \\
\hline Shoot $\mathrm{K}\left(\mathrm{mg} \mathrm{g}^{-1}\right)$ & $3.6 \pm 0.34 \mathrm{a}$ & $2.9 \pm 0.14 \mathrm{~b}$ & $2.8 \pm 0.13 \mathrm{~b}$ & $2.8 \pm 0.10$ & $3.4 \pm 0.25^{*}$ \\
\hline Root K (mg g $\left.{ }^{-1}\right)$ & $7.3 \pm 0.22 \mathrm{a}$ & $6.8 \pm 0.36 \mathrm{a}$ & $7.1 \pm 0.52 \mathrm{a}$ & $7.1 \pm 0.42$ & $7.1 \pm 0.15$ \\
\hline RGC (number of roots) & $3.7 \pm 1.02 \mathrm{~b}$ & $8.4 \pm 2.06 \mathrm{ab}$ & $12.5 \pm 1.95 \mathrm{a}$ & $7.4 \pm 1.85$ & $9.0 \pm 1.84$ \\
\hline
\end{tabular}

Means in the fertilisation treatments with the same letter indicate no significant difference $(P>0.05)$.

* Significant differences between shading regimes.

Differences among fertilisation treatments appeared in the first growing season (data not shown) but they increased after the second growing season. SVI of the high-fertilised holm oak seedlings was 2.8 and 1.6 times higher than the unfertilised and low-fertilised ones. RGR of the high-fertilised plants was 50 and $20 \%$ higher than the unfertilised and low-fertilised ones, respectively. Neither field mortality nor growth was affected by the shading regime in the nursery $\left(F_{1,10}=2.74, P=0.12\right.$ for mortality; $F_{1,10}=0.49$, $P=0.50$ for SVI; $F_{1,10}=1.92, P=0.19$ for RGR).

Field mortality was negatively related to the shoot dry mass, S/R and root $\mathrm{P}$ concentration of seedlings at planting, while SVI was positively related to the shoot dry mass and S/R (Fig. 2). Similar trends were obtained for RGR, although relationships were weaker $\left(r^{2}=0.22, P=0.054\right.$ for shoot mass; $r^{2}=0.22$, $P=0.059$ for $\mathrm{S} / \mathrm{R})$. A positive relationship of RGR with root $\mathrm{N}$ (Fig. 2) and root $\mathrm{P}$ concentration $\left(r^{2}=0.32, \quad P=0.016\right)$ was observed. Similarly, SVI was positively related to the root $\mathrm{N}$ and $\mathrm{P}$ concentration $\left(r^{2}=0.26, P=0.036\right.$ for $\operatorname{root} \mathrm{N}$; $r^{2}=0.23, P=0.048$ for root $\mathrm{P}$ ). Neither field mortality nor growth was significantly related either to the root mass or to the root and shoot $\mathrm{K}$ (data not shown).

Mortality was negatively related to RGC while RGR augmented with RGC increase (Fig. 3). A positive relationship between SVI and RGC was also observed $\left(r^{2}=0.29, P=0.02\right)$.

\section{Discussion}

\subsection{Plant morphology and nutrient content in response to nursery treatments}

Under the conditions of this study, $Q$. ilex seedlings exhibited a higher response to fertilisation than to shading. Fertilisation affected almost all the morphological and nutritional plant features, whereas the only morphological feature influenced by shading was $S / R$. Our nutrient results contrast with those reported by Valladares et al. (2000), which concluded that leaf N, $\mathrm{P}$ and $\mathrm{K}$ concentration, and several photosynthetic traits were more influenced by light than to fertilisation. This discrepancy might be due to the different fertilisation and light levels considered in both studies. Consistent with our results, Retana et al. (1999) reported that $Q$. ilex seedlings do not exhibit any significant change in growth and mass allocation under light levels above $36 \%$ of full sunlight. This low responsiveness to shading is considered a typical feature of late succession species as Q. ilex (Bazzaz and Miao, 1993). 

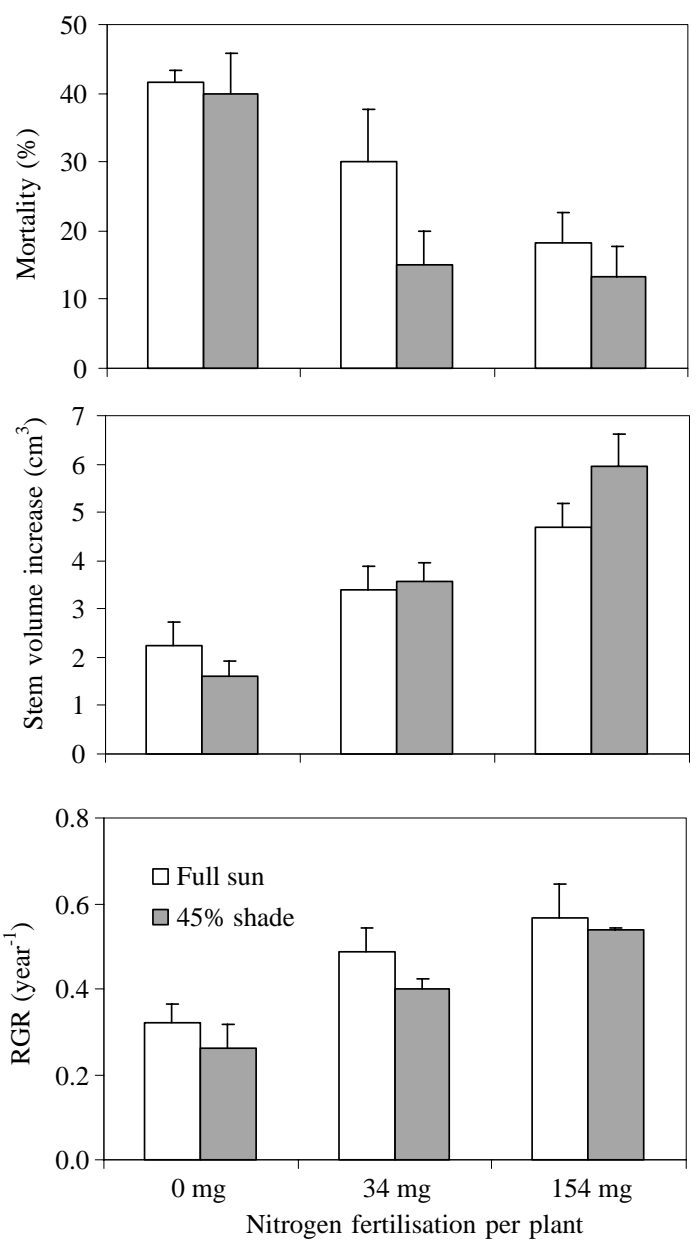

Fig. 1. Mortality, stem volume increase and relative growth rate two growing seasons after planting of $Q$. ilex seedlings that were grown in the nursery with different amount of nitrogen and under different shade regimes. Error bars are one standard error.

Shading reduced the $\mathrm{N}$ and $\mathrm{P}$ tissue concentrations but increased shoot $\mathrm{K}$ concentration. In other species, foliar $\mathrm{N}$ concentration tends to be reduced with increasing light availability (Welander and Ottosson, 2000; Evans et al., 2001). These differences might reflect species-specific responses of nutrient allocation to light, although the diminution of $\mathrm{N}$ and $\mathrm{P}$ nutrient concentration with shade can be also attributed to a reduction of nutrient uptake by both a high $\mathrm{S} / \mathrm{R}$ and by a low capacity of roots to absorb nutrients imposed by reduced light availability (Chapin, 1991).

As reported in other species, growth, leaf production, and $\mathrm{S} / \mathrm{R}$ in holm oak seedlings increased with nutrient supply (Green et al., 1994; Holopainen et al., 1995; Graff et al., 1999). The higher S/R was due to an increase in shoot growth but not to a reduction in the mass allocated to root. This response has also been observed in other Quercus species (Canham et al., 1996; Berger and Glatzel, 2001), suggesting that these species have a conservative pattern of root mass allocation in response to variations in mineral nutrients.

Leaf $\mathrm{N}$ concentration tends to be promoted by high $\mathrm{N}$ fertilisation (Miller and Timmer, 1994; Holopainen et al., 1995). Surprisingly, no differences in shoot $\mathrm{N}$ concentration were found among fertilisation treatments, although root $\mathrm{N}$ concentration increased with a higher $\mathrm{N}$ supply. Shoot $\mathrm{N}$ concentration did not increase with fertilisation because the rate of shoot growth probably paralleled that of $\mathrm{N}$ uptake. This interpretation is supported by the fact that root mass did not differ among treatments but root $\mathrm{N}$ concentration increased with fertilisation, permitting increase in root $\mathrm{N}$.

Our results indicate that the high $\mathrm{N}$ fertilisation (154 mg) was not at $\mathrm{N}$ supply needed to achieve luxury consumption in $Q$. ilex seedlings. In a congener species ( $Q$. petraea), $\mathrm{N}$ supply of more than $400 \mathrm{mg}$ per plant was needed to induce luxury consumption (Berger and Glatzel, 2001). A rough estimation of the nitrogen use efficiency (the ratio between plant $\mathrm{N}$ content and the total $\mathrm{N}$ supplied) for the highfertilised seedlings was $30 \%$. This value is smaller than that observed in 2-year old $Q$. petraea seedlings in which it varied from 37 to $61 \%$ in plants fertilised with $400 \mathrm{mg} \mathrm{N}$ (Berger and Glatzel, 2001). It is also smaller than the NUE of the Mediterranean pine $P$. halepensis that varied between 54 and $41 \%$ in plants receiving 120 and $180 \mathrm{mg}$ of $\mathrm{N}$, respectively (Oliet et al., 1999). These data indicate that $Q$. ilex seedlings have a low $\mathrm{N}$ uptake capacity and that a very high $\mathrm{N}$ fertilisation should be supplied to achieve luxury consumption during their cultivation in the nursery.

\subsection{Field performance and its relationship with plant attributes}

Field results revealed that high-fertilised plants had lower mortality and greater growth than the unfertilised and low-fertilised seedlings. On the contrary, shading in the nursery had no influence on field 

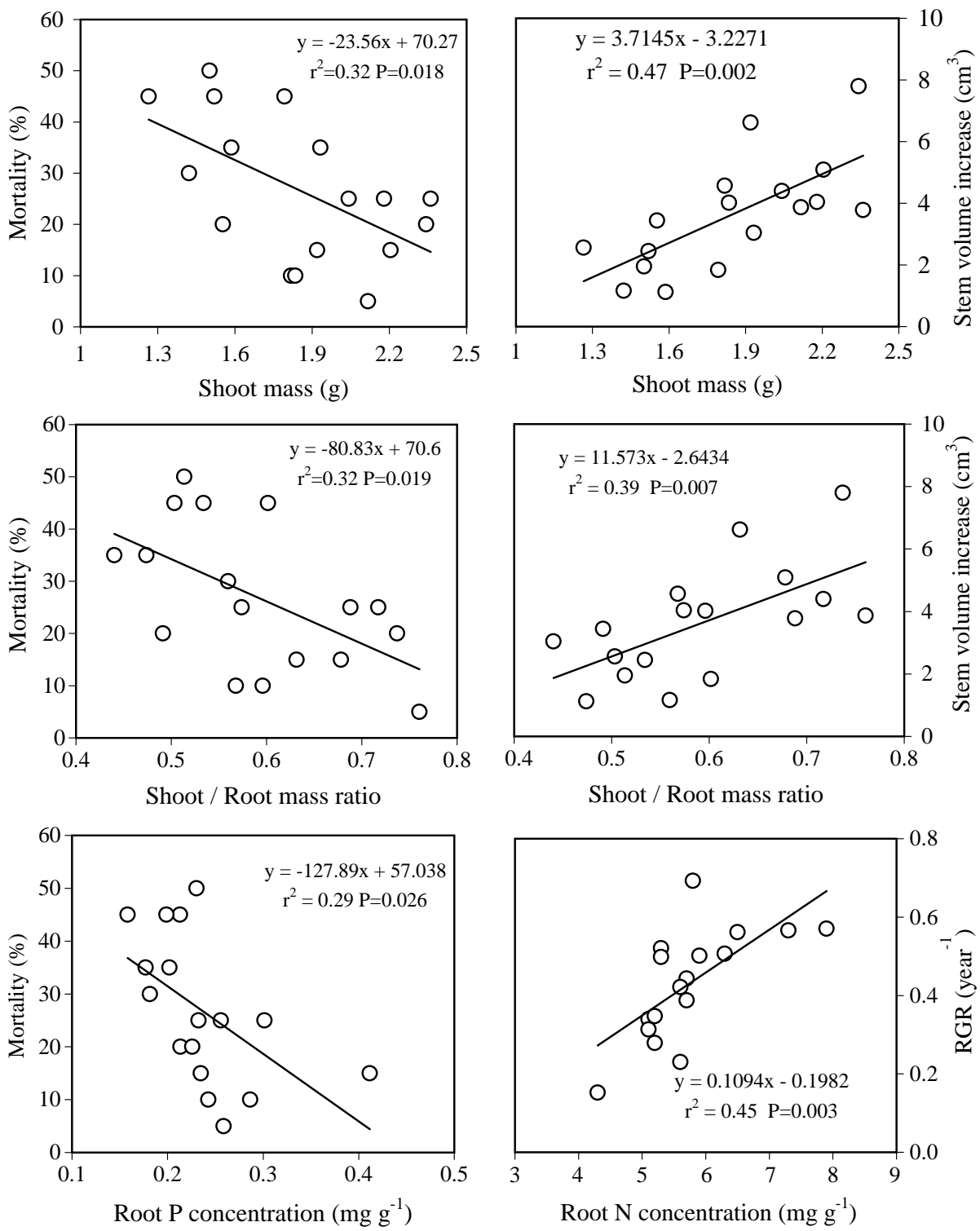

Fig. 2. Relationship of field mortality, stem volume increase and relative growth rate with several functional attributes of $Q$. ilex seedlings determined before planting.

performance of holm oak. Positive effects of nursery fertilisation on the field performance of plantations have been reported in both non-Mediterranean and in Mediterranean conifers (Timmer and Aidelbaum, 1996; van den Driessche, 1982, 1992; Oliet et al., 1997). Survival and growth in Ceratonia siliqua, a Mediterranean broadleaf evergreen tree, was enhanced by increasing nursery $\mathrm{P}$ fertilisation but not by $\mathrm{N}$ fertilisation (Planelles et al., 2001).

Outplanting performance of holm oak seedlings was related to the changes in plant size and in biomass allocation induced by nursery treatments. Low S/R and small shoot sizes have been considered drought resistance traits (Leiva and Fernández-Alés, 1998; 

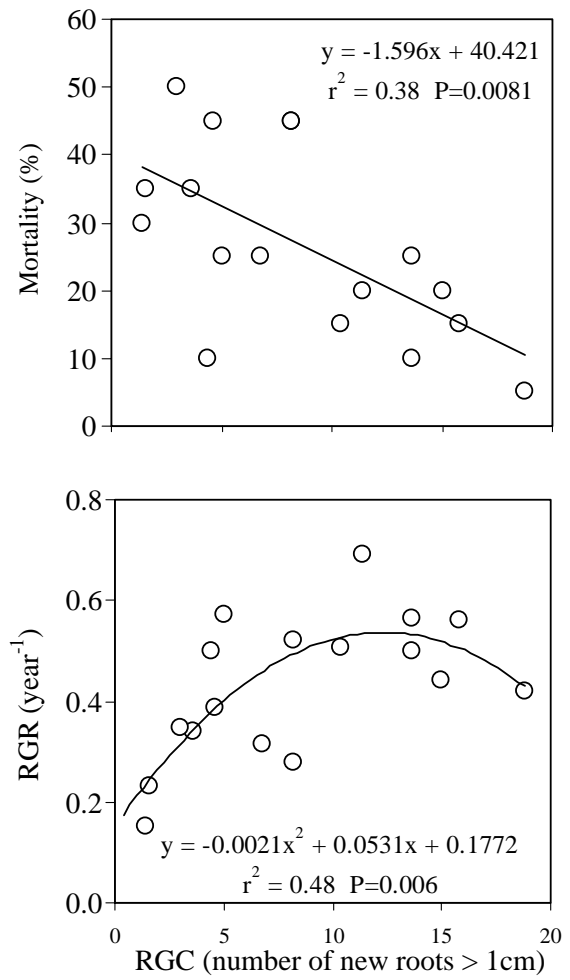

Fig. 3. Relationship of field mortality and relative growth rate with changes in the root growth capacity of $Q$. ilex seedlings.

Lloret et al., 1999). However, we found that holm oak seedlings with the largest shoots and with a higher $\mathrm{S} / \mathrm{R}$ had lower mortality and larger growth than those with the opposite attributes. Similar results have been observed in several species both in mesic climates (Barnett, 1984; Mexal and Landis, 1990) and in plantations under dry conditions (van den Driessche, 1992; Oliet et al., 1997). In Q. ilex, Cortina et al. (1997) reported a positive relationship between the shoot height of seedlings at planting and their field survival. However, our results disagree with those of Broncano et al. (1998), which reported that fertilisation enhanced mortality of $Q$. ilex seedlings by mainly affecting the large high-fertilised plants. This difference might be explained by the contrasting experimental conditions in both studies. Thus, Broncano et al. (1998) did not make field plantations and performed all their experiment growing the seedlings in $180 \mathrm{~cm}^{3}$ pots, in which plants with large shoots and high $S / R$ can experience water stress earlier than those with the opposite traits (Stewart and Bernier, 1995). In contrast to shoot size and S/R, outplanting performance was not related to root mass, which is in accordance with the lack of differences in root growth among nursery treatments.

Field growth was also related to the $\mathrm{N}$ and $\mathrm{P}$ concentrated in the root that, on an average, contained $46 \%$ of total seedling's nitrogen. This result is in accordance with the fact that in Mediterranean Quercus saplings, root is an important source of $\mathrm{N}$ for growing shoots (Silla, 2001). In contrast, field performance was not related to shoot $\mathrm{N}$, as reported in other species (van den Driessche, 1991; Oliet et al., 1997). Relative difference in root $\mathrm{N}$ among treatments was $47.5 \%$, whereas relative difference in shoot $\mathrm{N}$ was only $22 \%$, which is probably too low for explaining differences of field performance.

The outplanting results obtained in this study are relevant for the afforestation with $Q$. ilex in dry continental Mediterranean sites as they demonstrate that, contrary to what is commonly assumed, seedlings with small shoots and low S/R and nutrient concentration do not necessarily have better field performance under Mediterranean conditions. The poor performance of seedlings with small shoots and low $\mathrm{S} / \mathrm{R}$ might be attributed to an unbalanced carbon economy during their establishment phase and the summer period. Nevertheless, other causes as differences in drought tolerance induced by the different fertilisation of the plants (Tan and Hogan, 1995) might also explain the observed results.

Fertilisation strongly enhanced RGC a response that has also been reported in conifer species and attributed to the differences in photosynthetic rate linked with differences in foliage N (van den Driessche, 1992). In the present study, unfertilised and high-fertilised plants did not differ in photosynthetic rate (P. Villar-Salvador, unpublished data) but RGC was positively correlated with shoot size, suggesting that a physiological process linked with the size of the shoots, for instance the total assimilation capacity of the individuals or the amount of stored nutrients and non-structural carbohydrates, might have determined part of the RGC differences among treatments. RGC has been considered as a predictor of the outplanting performance because it is a measure of the vigour of the plants and/or the stress resistance of plants (Burdett et al., 1983; Simpson, 1990). In accordance with this, plants with a higher RGC showed a 
lower mortality and grew more than those with low RGC.

\section{Conclusions}

The results of this study demonstrate that $\mathrm{N}$ fertilisation in the nursery is an important tool for enhancing the field performance of $Q$. ilex in Mediterranean continental plantations. High fertilisation strongly reduced the high field mortality typical of this species and enhanced its growth, in spite of that the highfertilised plants presented larger shoots and higher shoot to root ratio. Shading of $45 \%$ in the nursery had no influence on the field development of holm oak seedlings, which can be cultivated in the nursery under full sun whenever appropriate irrigation is provided.

\section{Acknowledgements}

This study has been supported by the funds of the Spanish Ministry of Environment and by the projects CICYT FOA97-1652, Ren2000-0163-P4-05, and AGL2001-1061 of the Spanish Ministry of Science and Technology. Comments and suggestions made by Pilar Castro, Juan Oliet, David South, and two anonymous reviewers improved the manuscript.

\section{References}

Aranda, I., Gil, L., Pardos, J.A., 2001. Effects of thinning in a Pinus sylvestris L. stand on foliar water relations of Fagus sylvatica L. seedlings planted within the pinewood. Trees Struct. Funct. 15, 358-364.

Baeza, M.J., Pastor, A., Martín, J., Ibáñez, M., 1991. Mortalidad post-implantación en repoblaciones de Pinus halepenesis, Quercus ilex, Ceratonia siliqua y Tetraclinis articulata en la provincia de Alicante. Stvdia Oecol. 8, 139-146.

Barnett, J.P., 1984. Relating seedling physiology to survival and growth in container-grown southern pines. In: Duryea, M.L., Brown, G.N. (Eds.), Seedling Physiology and Reforestation Success. Martinus Nijhoff/Dr. W. Junk Publishers, Dordrecht, pp. 157-176.

Bazzaz, F.A., Miao, S.L., 1993. Successional status, seed size, and responses of tree seedlings to $\mathrm{CO}_{2}$, light, and nutrients. Ecology 74, 104-112.

Berger, T.W., Glatzel, G., 2001. Response of Quercus petraea seedlings to nitrogen fertilization. For. Ecol. Manage. 149, $1-14$.
Bocio, I., de Simón, E., Navarro, F.B., Ripoll, M.A., 2001. Efecto de diferentes procedimientos de preparación del suelo en la forestación de tierras agrarias. In: Proceedings of the III Congreso Forestal Español, vol. 3, Sociedad Española de Ciencias Forestales, Granada, Spain, pp. 317-322.

Broncano, M.J., Riba, M., Retana, J., 1998. Seed germination and seedling performance of two Mediterranean tree species, holm oak (Quercus ilex L.) and Aleppo pine (Pinus halepensis Mill.): a multifactor experimental approach. Plant Ecol. 138, 17-26.

Burdett, A.N., Simpson, D.G., Thompson, C.F., 1983. Root development and plantation establishment. Plant Soil 71, 103-110.

Callaway, R.M., 1992. Morphological and physiological responses of three California oak species to shade. Int. J. Plant Sci. 153, 434-441.

Canham, C.D., Berkowitz, A.R., Kelly, V.R., Lovett, G.M., Ollinger, S.V., Schnurr, J., 1996. Biomass allocation and multiple resource limitation in tree seedlings. Can. J. For. Res. 26, 1521-1530.

Chapin, F.S., 1991. Effects of multiple stresses on nutrient availability and use. In: Mooney, H.A., Winner, W.E., Pell, E.J., Chu, E. (Eds.), Response of Plants to Multiple Stresses. Academic Press, San Diego, pp. 67-88.

Cortina, J., Valdecantos, A., Seva, J.P., Vilagrosa, A., Bellot, J., Vallejo, R., 1997. Relación tamaño-supervivencia en plantones de especies arbustivas y arbóreas mediterráneas producidas en vivero. In: Proceedings of the II Congreso Forestal Español, vol. 3, Sociedad Española de Ciencias Forestales and Gobierno de Navarra, Pamplona, Spain, pp. 159-164.

Evans, C.A., Miller, E.K., Friedland, A.J., 2001. Effect of nitrogen and light on nutrient concentrations and associated physiological responses in birch and fir seedlings. Plant Soil 236, 197207.

Graff, J.E., Hermann, R.K., Zaerr, J.B., 1999. Dry matter and nitrogen allocation in western redcedar, western hemlock, and Douglas fir seedlings grown in low- and high-N soils. Ann. For. Sci. 56, 529-538.

Green, T.H., Mitchell, R.J., Gjerstad, D.H., 1994. Effects of nitrogen on the response of loblolly pine to drought. New Phytol. 128, 145-152.

Holopainen, J.K., Rikala, R., Kainulainen, P., Oksanen, J., 1995. Resource partitioning to growth, storage and defence in nitrogen-fertilized Scots pine and susceptibility of the seedlings to the tarnished plant bag Lygus rugulipennis. New Phytol. 131, 521-532.

Landis, T.D., 1985. Mineral nutrition as an index of seedling quality. In: Duryea, M.L. (Ed.), Evaluating Seedling Quality: Principles, Procedures, and Predictive Abilities of Major Tests. Forest Research Laboratory, Oregon State University, Corvallis, pp. 29-48.

Leiva, M.J., Fernández-Alés, R., 1998. Variability in seedling water status during drought within a Quercus ilex subsp. ballota population, and its relation to seedling morphology. For. Ecol. Manage. 111, 147-156.

Lloret, F., Casanovas, C., Peñuelas, J., 1999. Seedling survival of Mediterranean shrubland species in relation to root: shoot ratio, seed size and water and nitrogen use. Funct. Ecol. 13, 210-216. 
Lookingbill, T.R., Zavala, M., 2000. Spatial pattern of Quercus ilex and Quercus pubescens recruitment in Pinus halepensis dominated woodlands. J. Veg. Sci. 11, 607-612.

Mexal, J.G., Landis, T.D., 1990. Target seedling concepts: height and diameter. In: Rose, R., Campbell, S.J., Landis, T.D. (Eds.), Target Seedling Symposium. UDSA Forest Service, Roseburg, Oregon, pp. 17-35.

Miller, B.D., Timmer, V.R., 1994. Steady-state nutrition of Pinus resinosa seedlings: response to nutrient loading, irrigation and hardening regimes. Tree Physiol. 14, 1327-1338.

Oliet, J.A., Planelles, R., López, M., Artero, F., 1997. Efecto de la fertilización en vivero sobre la supervivencia en plantación de Pinus halepensis. Cuadernos de la Sociedad Española de Ciencias Forestales 4, 69-79.

Oliet, J.A., Segura, M.L., Martín-Domínguez, F., Blanco, E., Serrada, R., López Arias, M., Artero, F., 1999. Los fertilizantes de liberación controlada lenta aplicados a la producción de planta forestal de vivero. Efecto de dosis y fórmulaciones sobre la calidad de Pinus halepensis Mill. Investigaciones Agrarias: Sistema y Recursos Forestales 8, 207-228.

Planelles, R., Oliet, J.A., Artero, F., López, M., 2001. Efecto de distintas dosis N-P-K sobre la calidad funcional de planta de Ceratonia siliqua. Respuesta en plantación. In: Proceedings of the III Congreso Forestal Español, vol. 3. Sociedad Española de Ciencias Forestales Granada, España, 2001, pp. 599-605.

Retana, J., Espelta, J.M., Gracia, M., Riba, M., 1999. Seedling recruitment. In: Rodà, F., Retana, J., Gracia, C.A., Bellot, J. (Eds.), Ecology of Mediterranean Evergreen Oak Forests, Springer, Berlin, pp. 89-103.

Rey-Benayas, J.M., 1998. Growth and mortality in Quercus ilex L. seedlings after irrigation and artificial shading in Mediterranean set-aside agricultural lands. Ann. Sci. For. 55, 801-807.

Silla, F., 2001. Producción y ciclo de nutrientes en reforestaciones de quercíneas. Ph.D. Thesis. University of Salamanca.

Simpson, D.G., 1990. Frost hardiness, root growth capacity, and field performance relationships in interior spruce, lodgepole pine, douglas-fir, and western hemlock seedlings. Can. J. For. Res. 20, 566-572.

Stewart, J.D., Bernier, P.Y., 1995. Gas exchange and water relations of three sizes of containerized Picea mariana seedlings subjected to atmospheric and edaphic water stress under controlled conditions. Ann. Sci. For. 52, 1-9.

Tan, W., Hogan, G.D., 1995. Effects of nitrogen limitation on water relations of jack pine (Pinus banksiana Lamb.) seedlings. Plant Cell Environ. 18, 757-764.

Timmer, V.R., Aidelbaum, A.S., 1996. Manual for exponential nutrient loading of seedlings to improve outplanting performance on competitive forest sites. Technical Report No. TR-25. NODA/NFP, Ministry of Natural Resources of Ontario, Ontario.

Timmer, V.R., Armstrong, G., Miller, B.D., 1991. Steady-state nutrient preconditioning and early outplanting performance of containerized black spruce seedlings. Can. J. For. Res. 21, 585-594.

Valladares, F., Martínez-Ferri, E., Balaguer, L., Pérez-Corona, E., Manrique, E., 2000. Low leaf-level response to light and nutrients in Mediterranean evergreen oaks: a conservative resource-use strategy? New Phytol. 148, 79-91.

van den Driessche, R., 1982. Relationship between spacing and nitrogen fertilization of seedlings in the nursery, seedling size, and outplanting performance. Can. J. For. Res. 12, 865-875.

van den Driessche, R., 1991. Effects of nutrients on stock performance in the forest. In: van den Driessche, R. (Ed.), Mineral Nutrition of Conifer Seedlings. CRC Press, Boca Raton, pp. 229-260.

van den Driessche, R., 1992. Changes in drought resistance and root growth capacity of container seedlings in response to nursery drought, nitrogen, and potassium. Can. J. For. Res. 22, $740-749$.

Welander, N.T., Ottosson, B., 2000. The influence of low light, drought and fertilization on transpiration and growth in young seedlings of Quercus robur L. For. Ecol. Manage. 127, 139-151. 